\title{
Chemical Constitution and Antimicrobial Activity of Kombucha Fermented Beverage
}

\author{
Abdul-Raouf Al-Mohammadi ${ }^{1}$, Ahmed A. Ismaiel ${ }^{2}$, Rehab A. Ibrahim ${ }^{2}$, Ahmed H. Moustafa ${ }^{3}$ (D) \\ Azza Abou Zeid ${ }^{2}$ and Gamal Enan 2,* (D) \\ 1 Department of Sciences, King Khalid Military Academy, Riyadh 11459, Saudi Arabia; \\ almohammadi26@hotmail.com \\ 2 Department of Botany and Microbiology, Faculty of Science, Zagazig University, Zagazig 44519, Egypt; \\ ahmedismaiel@zu.edu.eg (A.A.I.); rehabatef@yahoo.com (R.A.I.); azza.abozeid@yahoo.com (A.A.Z.) \\ 3 Department of Chemistry, Faculty of Science, Zagazig University, Zagazig 44519, Egypt; \\ ah_hu_mostafa@yahoo.com \\ * Correspondence: gamalenan@ymail.com; Tel.: +20-100-987-7015 or +20-100-905-3713
}

Citation: Al-Mohammadi, A.-R.; Ismaiel, A.A.; Ibrahim, R.A.; Moustafa, A.H.; Abou Zeid, A.; Enan, G. Chemical Constitution and Antimicrobial Activity of Kombucha Fermented Beverage. Molecules 2021, 26, 5026. https://doi.org/10.3390/ molecules26165026

Academic Editor: Francesco Cacciola

Received: 17 July 2021

Accepted: 17 August 2021

Published: 19 August 2021

Publisher's Note: MDPI stays neutral with regard to jurisdictional claims in published maps and institutional affiliations.

Copyright: (c) 2021 by the authors. Licensee MDPI, Basel, Switzerland. This article is an open access article distributed under the terms and conditions of the Creative Commons Attribution (CC BY) license (https:// creativecommons.org/licenses/by/ $4.0 /)$.

\begin{abstract}
Kombucha is a traditional beverage of sweetened black tea fermented with a symbiotic association of acetic acid bacteria and yeasts. In this study, kombucha fermented beverage (KFB) appeared to include nine chemical groups (alcohols, acids, lactones, condensed heterocyclic compounds, antibiotics, esters, aldehydes, fatty acids, and alkaloids) of many bioactive metabolites, as elucidated by gas chromatography-mass spectrometry (GC-MS) and IR spectra. The fermented metabolic components of KFB seem collectively to act in a synergistic action giving rise to the antimicrobial activity. Four types of kombucha preparations (fermented, neutralized, heat-treated and unfermented) were demonstrated with respect to their antimicrobial activity against some pathogenic bacterial and fungal strains using agar well diffusion assay. KFB exerted the strongest antimicrobial activities when compared with neutralized and heat-treated kombucha beverages (NKB and HKB). Staphylococcus aureus ATCC6538 (S. aureus) and Escherichia coli ATCC11229 (E. coli) were the organisms most susceptible to the antimicrobial activity of kombucha beverage preparations. Finally, the KFB preparation showed remarkable inhibitory activity against $S$. aureus and $E$. coli bacteria in a brain heart infusion broth and in some Egyptian fruit juices (apple, guava, strawberry, and tomato). These data reveal that kombucha is not only a prophylactic agent, but also appears to be promising as a safe alternative biopreservative, offering protection against pathogenic bacteria and fungi.
\end{abstract}

Keywords: kombucha tea; kombucha fermented beverage (KFB); GC-MS analysis; pathogenic bacteria and fungi; antimicrobial activity; Egyptian fruit juices

\section{Introduction}

Probiotics are live microorganisms that when administered in adequate amounts, improve many nutritional and digestive functions [1,2]. After a long history of safe use of probiotics in fermented food products and an increased recognition of their beneficial human health effects, in addition to their significant potential use as therapeutic options for a variety of diseases, the food industry has become increasingly interested in these types of microorganisms [3-10]. The mechanisms underlying the beneficial effects of probiotics are likely to be multifactorial. These mechanisms include production of various antimicrobial agents, modification of the gut microbiota, competitive adherence to the mucosa and epithelium, strengthening of the gut epithelial barrier and modulation of the immune system [1]. The most widely used probiotics to date are several genera of both lactic and acetic acid bacteria as well as yeasts; they are applied in many functional foods and dietary supplements [1]. Furthermore, probiotics have been reported to display a protective role by direct competing with intestinal pathogens through the release of antibacterial substances such as bacteriocins that could kill the multidrug resistant bacteria $[4,11-13]$ or metabolites 
such as acetic acid and lactic acid $[1,10]$. Probiotic yeasts such as Saccharomyces cerevisiae and $S$. boulardii have also been demonstrated to confer health benefits $[14,15]$. Thus, there is an urgent need to continue research on other probiotic sources with unique prophylactic and antimicrobial characteristics.

Kombucha is a slightly sweet and acidic beverage that is generally prepared by fermenting sweetened black tea with the tea fungus, a symbiotic culture of bacteria and yeast (SCOBY). This symbiotic consortium includes mainly acetic acid bacteria and different yeasts [16]. Kombucha colony/mat represents a symbiotic relationship of yeasts and bacteria, and their composition is highly variable. As reviewed by Jayabalan et al. [16], the most abundant bacteria in this culture belong to the genera Acetobacter and Gluconobacter. The main bacterium is Acetobacter xylinum. In addition to acetic acid bacteria, a broad spectrum of yeast species belonging to Saccharomyces, Saccharomycodes, Schizosaccharomyces, Zygosaccharomyces, Brettanomyces, Candida, Torulospora, Kloeckera, Pichia, Mycotorula, and Mycoderma are found in kombucha. The basis of symbiotic relationship coincides in the mechanism by which yeasts convert sucrose into glucose and fructose by invertase and produce ethanol via metabolic pathways. Acetic acid bacteria convert glucose to gluconic acid and ethanol to produce acetic acid [16]. Fermentation of kombucha results in the formation of two portions: a floating cellulosic pellicle layer and the sour liquid broth (fermented broth) [17].

Kombucha displayed potential prophylactic activities including weight loss, treatment of metabolic diseases, arthritis, indigestion, cancer and acquired immunodeficiency syndrome (AIDS) [18-20]. Regular ingestion of kombucha beverage showed a significant role in weight gain inhibition and life elongation [21]. The prophylactic and antioxidant activities of kombucha are attributed to a variety of active components produced during fermentation, including organic acids (mainly acetic, gluconic, glucuronic acid), sugars (sucrose, glucose, and fructose), water-soluble vitamins (B1, B6, B12 and C), amino acids, biogenic amines, purines, pigments, lipids, proteins, hydrolytic enzymes, ethanol, carbon dioxide, polyphenols, minerals, anions D-saccharic acid-1,4-lactone, and metabolic products of yeasts and bacteria [22].

Kombucha has been reported to exert antimicrobial activity against Candida krusei CCM 8271, C. glabrata CCM 8270, C. albicans CCM 8186, C. tropicalis CCM 8223, Haemophilus influenzae CCM 4454 and Escherichia coli CCM 3954 [9], Staphylococcus epidermidis CIP 106510, S. aureus ATCC 25923, Micrococcus luteus NCIMB 8166, Salmonella typhimurium LT2, E. coli ATCC 35218, Listeria monocytogenes ATCC 19115, Pseudomonas aeruginosa ATCC 27853 [23]. Kombucha has been found to contain many metabolites with antimicrobial activity such as organic acids, in particular acetic acid and catechins, in addition to antibiotic substances which were found to inhibit Gram-positive and Gram-negative microorganisms [24].

The consumption of non-dairy nutraceuticals, increased people with lactose intolerance, and the tendency of individuals to veganism are strong justifications to find new, safe, non-dairy probiotic products with prophylactic activities $[25,26]$. Kombucha and fermented herb drinks may be alternatives for functional dairy products for individuals with lactose intolerance [27]. In this study, we demonstrated kombucha's antimicrobial activity in vitro and in fruit juices. The feasibility of application of kombucha as an additive in fruit juices in order to protect unrefrigerated juices from bacterial and fungal contamination was investigated. Furthermore, the kombucha's bioactive compounds by means of available instrumental analysis were identified.

\section{Results}

Kombucha fermented beverage (KFB) was prepared under our experimental conditions using black tea (1.2\%) sweetened with sucrose $(10 \%)$ at an initial $\mathrm{pH}$ of 5.0 and inoculated with $3 \%(w / v)$ freshly grown tea fungus followed by incubation at $30{ }^{\circ} \mathrm{C}$ for about 14 days. The final $\mathrm{pH}$ was found to be decreased to 3.0.

In the current study, KFB was subjected to GC-MS analysis to detect its bioactive compounds. The results obtained (Table 1 and Figure 1) represent the names and classes, in 
addition to molecular formula and molecular weight, of the nine chemical categories produced. The main compounds in the KFB preparation were heterocylic alcohols: 2-hydroxy methyl furan, 2-(4-hydroxyphenyl) ethanol; heterocyclic acids: 1,2,3,4-tetrahydro-2,4 dioxo5-carboxymethyluracil, hexadecanoic acid, ethyl-2-[2,2-dimethylcyclopropanecarboxylate (cyclopropane carboxylic acid); lactone: 3,5-dihydroxy-6-methyl-2,3-diydroxy-4H-pyran-4one, 4-hexyl-2,5-dihydro-2,5-dioxo-3-furan acetic acid, 3-methoxy-2,4,6-trimethylcyclohex2-enone, 3,7-dimethyl-1-[2-(vinyloxy) ethyl-3,7-dihydro- $1 H$-purine-2,6-dione, S-[(2E)-1,3diphenyl-2-butenyl] dimethylthio carbamate; condensed heterocyclic cpd: 2,3-dihydroben zofuran, 7,7-dimethyl-1-isobutylhexahydro-2-benzofuran-3a (3H)-ol; antibiotics: cypermethrin, cyhalothrin; heterocyclic esters: 5-acetoxymethyl-2-furaldehyde; heterocyclic aldehydes: 5-hydroxymethyl furfural; unsat. fatty acids: 2-hexadecenoic acid; alkaloides: 1,3,7-trimethyl-3,7-dihydro-1 $H$-purine-2,6-dione. In addition, the IR spectrum (Figure 2) showed the presence of bands at $3380 \mathrm{~cm}^{-1}$ for $\mathrm{CH}, 2205 \mathrm{~cm}^{-1}$ for $\mathrm{C} \equiv \mathrm{N}, 1742 \mathrm{~cm}^{-1} \mathrm{C}=\mathrm{O}$ for ester, $1715 \mathrm{~cm}^{-1} \mathrm{C}=\mathrm{O}$ for ketone, $1695 \mathrm{~cm}^{-1} \mathrm{C}=\mathrm{O}$ for aldehyde conjugated with double bond, $1645 \mathrm{~cm}^{-1} \mathrm{C}=\mathrm{O}$ for amide and at $1615 \mathrm{~cm}^{-1}$ for $\mathrm{C}=\mathrm{N}$. In addition, a band at $1150 \mathrm{~cm}^{-1}$ was characterized for the -O-, ether.

Table 1. Putative identification of the chemical components from KFB when subjected to GC-MS (gas liquid chromatographicmass spectrometry).

\begin{tabular}{|c|c|c|c|c|c|}
\hline & Classification and Compound Name & $\begin{array}{l}\text { Mol.wt \& Mol. } \\
\quad \text { Formula }\end{array}$ & $\begin{array}{l}\text { Parent Ion } \\
\quad\left(\mathrm{M}^{+}\right)\end{array}$ & Area & $\begin{array}{c}\text { Base Peak } \\
(\mathrm{m} / \mathrm{z}) \\
(\mathbf{1 0 0 \% )}\end{array}$ \\
\hline \multicolumn{6}{|c|}{ Group A: Heterocyclic Alcohols } \\
\hline 1. & 2-Hydroxy methyl furan & $\mathrm{C}_{5} \mathrm{H}_{6} \mathrm{O}_{2}(98)$ & 99 & 1.35 & 98.0 \\
\hline 2. & 2-(4-Hydroxyphenyl) ethanol & $\mathrm{C}_{8} \mathrm{H}_{10} \mathrm{O}_{2}(138.0)$ & 138.0 & 0.83 & 1.07 \\
\hline & Group B: Heterocyclic Acids & & & & \\
\hline 1. & 1,2,3,4-Tetrahydro-2,4-dioxo-5-carboxy methyl uracil & $\mathrm{C}_{6} \mathrm{H}_{6} \mathrm{~N}_{2} \mathrm{O}_{4}(170.0)$ & 170.0 & 0.30 & 112.0 \\
\hline 2. & $\begin{array}{l}\text { Hexadecanoic acid } \\
\mathrm{CH}_{3}\left(\mathrm{CH}_{2}\right)_{14}-\mathrm{COOH}\end{array}$ & $\mathrm{C}_{16} \mathrm{H}_{32} \mathrm{O}_{2}(256.0)$ & 256.0 & 0.66 & 73.0 \\
\hline 3. & $\begin{array}{l}\text { Ethyl-2-[2,2-dimethylcyclopropanecarboxylate } \\
\text { (cyclopropane carboxylic acid) }\end{array}$ & $\begin{array}{l}\mathrm{C}_{10} \mathrm{H}_{14} \mathrm{Cl}_{2} \mathrm{O}_{2} \\
\quad(236.0)\end{array}$ & 236.0 & 0.42 & 163.0 \\
\hline \multicolumn{6}{|c|}{ Group C: Lactone } \\
\hline 1. & 3,5-Dihydroxy-6-methyl-2,3-diydroxy-4H-pyran-4-one & $\mathrm{C}_{6} \mathrm{H}_{8} \mathrm{O}_{4}(144.0)$ & 144.0 & 0.85 & 43.0 \\
\hline 2. & 4-Hexyl-2,5-dihydro-2,5-dioxo-3-furan acetic acid & $\mathrm{C}_{12} \mathrm{H}_{16} \mathrm{O}_{5}(240.0)$ & 240.0 & 0.12 & 126.0 \\
\hline 3. & 3-Methoxy-2,4,6-trimethylcyclohex-2-enone & $\mathrm{C}_{10} \mathrm{H}_{16} \mathrm{O}_{2}(168.0)$ & 168.0 & 0.12 & 126.0 \\
\hline 4. & $\begin{array}{l}\text { 3,7-Dimethyl-1-[2-(vinyloxy) } \\
\text { ethyl-3,7-dihydro-1H-purine-2,6-dione }\end{array}$ & $\mathrm{C}_{11} \mathrm{H}_{14} \mathrm{~N}_{4} \mathrm{O}(250.0)$ & 250.0 & 0.55 & 180.0 \\
\hline 5. & $\begin{array}{l}\text { S-[(2E)-1,3-diphenyl-2-butenyl] dimethylthiocarbamate } \\
\text { Group D: Condensed Heterocyclic cpd }\end{array}$ & $\mathrm{C}_{19} \mathrm{H}_{21} \mathrm{NOS}$ (311.0) & 311.0 & 0.22 & 207.0 \\
\hline 1. & 2,3-Dihydrobenzofuran & $\mathrm{C}_{8} \mathrm{H}_{8} \mathrm{O}(120.0)$ & 120.0 & 0.47 & 0.91 \\
\hline 2. & $\begin{array}{l}\text { 7,7-Dimethyl-1-Isobutyl hexahydro-2-benzofuran-3a (3H)-ol } \\
\text { Group E: Antibiotics }\end{array}$ & $\mathrm{C}_{14} \mathrm{H}_{26} \mathrm{O}_{2}(226.0)$ & 226.0 & 0.51 & 159.0 \\
\hline 1. & Cypermethrin & $\begin{array}{c}\mathrm{C}_{22} \mathrm{H}_{19} \mathrm{Cl}_{2} \mathrm{NO}_{3} \\
(415.0)\end{array}$ & 415.0 & 0.30 & 163.0 \\
\hline 2. & Cyhalothrin & $\begin{array}{c}\mathrm{C}_{23} \mathrm{H}_{19} \mathrm{Co} \mathrm{F}_{3} \mathrm{NO}_{3} \\
(449.0)\end{array}$ & 449.0 & 0.30 & 181.0 \\
\hline 1. & $\begin{array}{l}\text { Group F: Heterocyclic Esters } \\
\text { 5-Acetoxymethyl-2-furaldehyde } \\
\text { Group G: Heterocyclic Aldehydes }\end{array}$ & $\mathrm{C}_{8} \mathrm{H}_{8} \mathrm{O}_{4}(168.0)$ & 168.0 & 0.38 & 126.0 \\
\hline 1. & $\begin{array}{l}\text { 5-Hydroxymethyl furfural } \\
\text { Group H: Unsat. Fatty Acids }\end{array}$ & $\mathrm{C}_{6} \mathrm{H}_{8} \mathrm{O}_{3}(126.0)$ & 126.0 & 13.45 & 97.0 \\
\hline 1. & $\begin{array}{l}\text { 2-Hexadecenoic acid } \\
\text { Group I: Alkaloids }\end{array}$ & $\mathrm{C}_{16} \mathrm{H}_{30} \mathrm{O}_{2}(254.0)$ & 254.0 & 0.40 & 43.0 \\
\hline 1. & 1,3,7-Trimethyl-3,7-dihydro- $1 H$-purine-2,6-dione (caffeine) & $\mathrm{C}_{8} \mathrm{H}_{10} \mathrm{~N}_{4} \mathrm{O}_{2}(194.0)$ & 194.0 & 69.24 & 109.0 \\
\hline
\end{tabular}




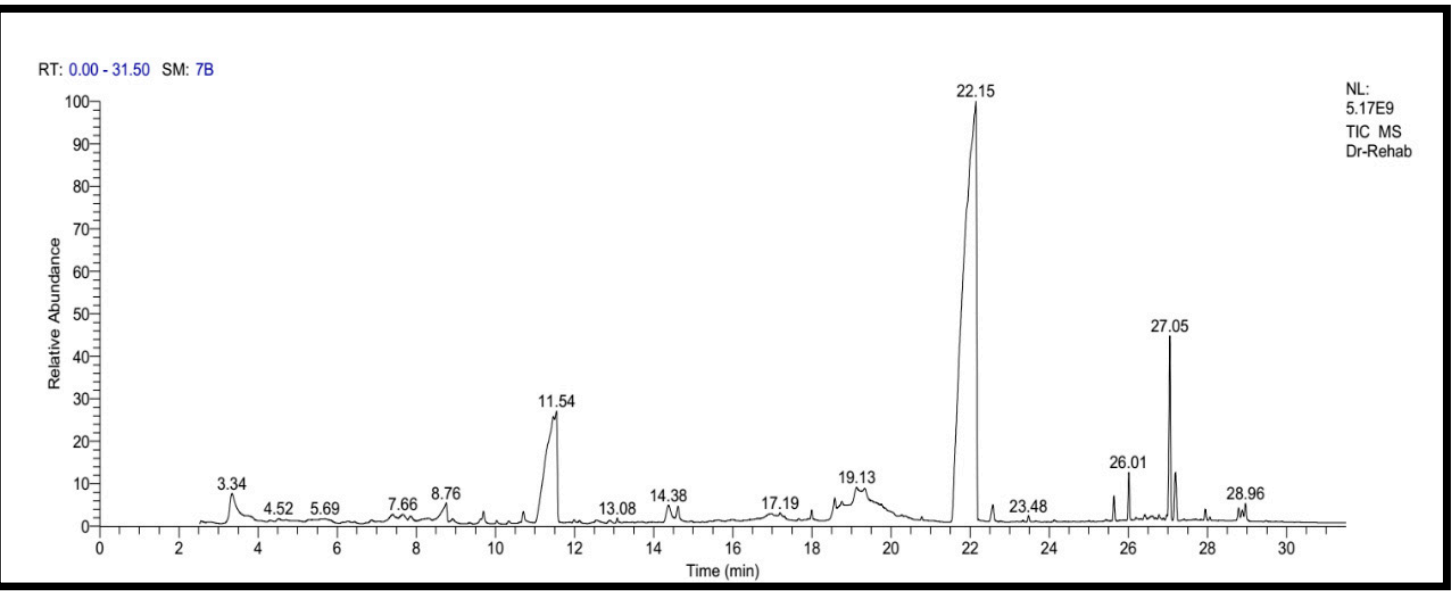

Figure 1. GC-MS analysis of KFB.

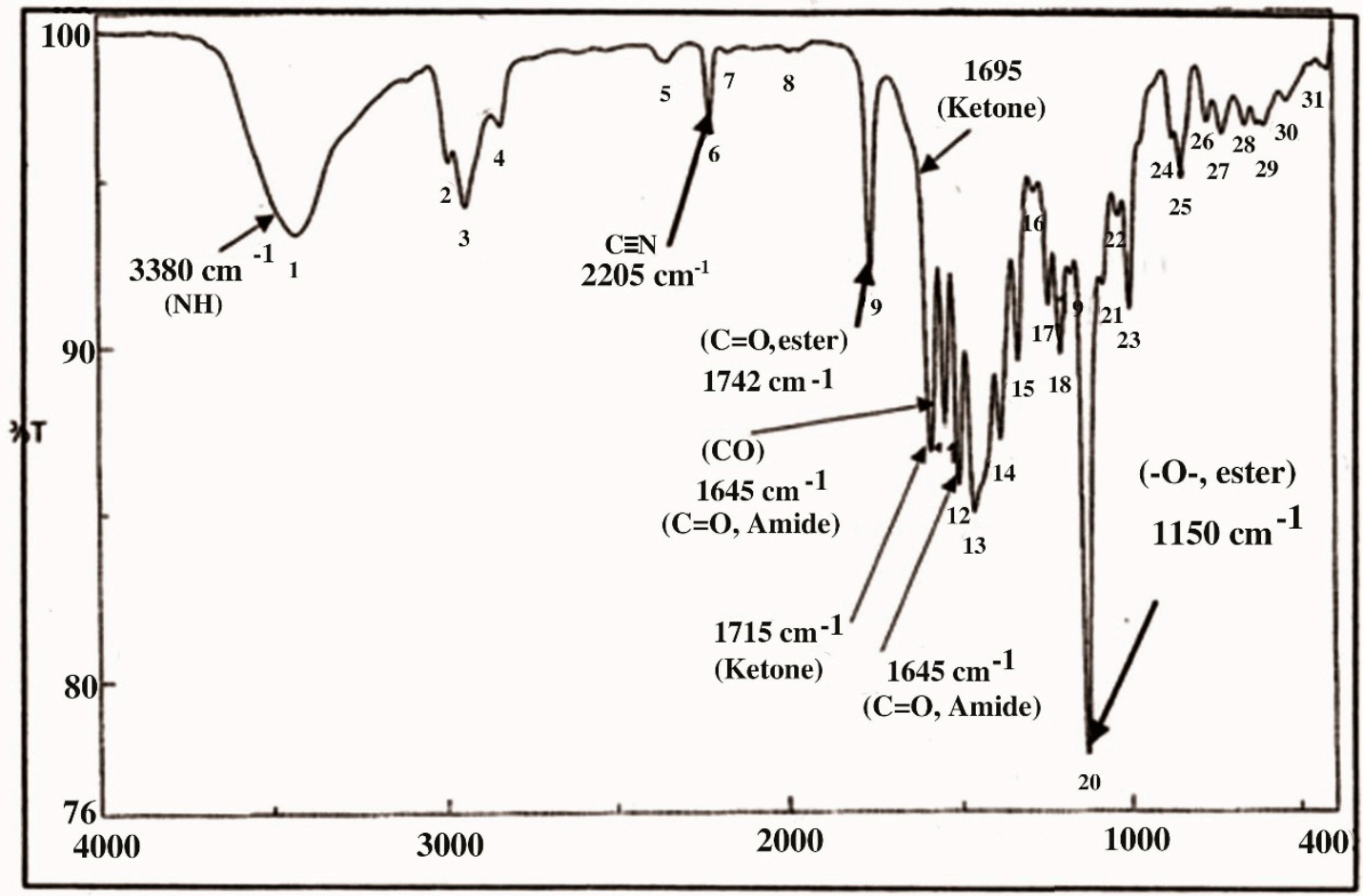

Wavenumber (cm-1)

Figure 2. IR spectrum in $\mathrm{KBr}$ (discs) for the extraction of KFB.

To check the bacterial status of kombucha, it was analyzed microbiologically on suitable media as described in the Materials and Methods. The microbial isolates were automatically identified by Viteck-2; the bacterial strains were found to belong Acetobacter xylinum, A. pasteurians, A. aceti (acetic acid bacteria), Lactobacillus fermentum and L. acidophilus (lactic acid bacteria). Additionally, the following yeasts were identified by API-yeasts kits: Saccharomyces cerevisiae and Schizosaccharomyces pombe. All the microbial cultures were studied with respect to their cell morphology and Gram staining. The microbial isolates were classified into two Gram-positive rods (lactic acid bacteria) and three Gram-negative rods (acetic acid bacteria). The vegetative yeast cultures were Gram-positive oval-shaped cells.

The antibacterial activities of the studied kombucha beverages, viz., KFB, NKB, HKB and $U K B$, against the pathogenic microorganisms tested are presented in Table 2. The results showed that $\mathrm{KFB}, \mathrm{NKB}$, and $\mathrm{HKB}$ have antimicrobial potency against all tested 
bacteria and fungi with varied activity. The three preparations can be arranged in the following descending order according to their antimicrobial potential: KFB $>$ HKB $>$ NKB. The unfermented UKB preparation showed no antimicrobial activity. Significant inhibition zone diameters of all the tested bacterial and fungal strains were obtained with the KFB preparation, compared with other kombucha preparations. Among the bacterial strains tested, S. aureus and E. coli were the most sensitive organisms, recording 19- and 18-mm inhibition zone diameters, respectively, upon employing KFB preparation and 12-mm inhibition zone diameter of both strains upon employing HKB preparation. The two preparations showed a good antifungal activity against $A$. flavus and $A$. niger with inhibition zones of about 12 and $9.5 \mathrm{~mm}$, respectively, in the case of the KFB preparation and 5.0 and $4.6 \mathrm{~mm}$, respectively, in the case of the HBK preparation.

Table 2. Antimicrobial activity of unfermented, fermented, neutralized and heat-denatured kombucha determined by the agar well diffusion method.

\begin{tabular}{clcccc}
\hline \multirow{2}{*}{ Tested Organism } & \multicolumn{5}{c}{ Inhibition Zone Diameters (mm) } \\
\cline { 2 - 6 } & UKB & KFB & NKB & HKB & $p$-Value \\
\hline Salmonella typhimurium ATCC14028 & N.A. & $14.0 \pm 0.2$ & $1.3 \pm 0.2$ & $10 \pm 0.1$ & 00.000 \\
List. Monocytogenes ATCC4957 & N.A. & $15 \pm 0.0$ & $1.0 \pm 0.0$ & $7 \pm 0.3$ & 0.000 \\
B. cereus ATCC14579 & N.A. & $14.5 \pm 0.18$ & $1.4 \pm 0.0$ & $8.5 \pm 0.0$ & 0.000 \\
S. aureus ATCC6538 & N.A. & $19 \pm 0.1$ & $7 \pm 0.0$ & $12 \pm 0.1$ & 0.000 \\
E. coli ATCC 11229 & N.A. & $18 \pm 0.25$ & $5.3 \pm 0.0$ & $12 \pm 0.0$ & 0.000 \\
A. flavus ATCC16872 & N.A. & $12 \pm 0.0$ & $1.1 \pm 0.1$ & $5.0 \pm 0.0$ & 0.000 \\
A. niger ATCC20611 & N.A. & $9.5 \pm 0.0$ & $0.9 \pm 0.2$ & $4.6 \pm 0.0$ & 0.000 \\
\hline
\end{tabular}

ATCC: American Type Culture Collection. N.A.: No activity.

Since the S. aureus bacterium (a Gram-positive bacterium) and the E. coli (a Gramnegative bacterium) were the most sensitive bacterial strains to the antimicrobial potential of the KFB preparation among the kombucha preparations, they were nominated for further experiments to demonstrate the efficacy of KFB in controlling the growth of both strains in $\mathrm{BHI}$ broth and fruit juices (apple, guava, strawberry, and tomato). Results on the inhibition of both bacterial strains by KFB in BHI broths are presented in Figure 3A,B. Growth of the control cells of either S. aureus (Figure 3A) or E. coli (Figure 3B) increased vigorously, reaching an increase of almost $9 \log$ cycles within $72 \mathrm{~h}$. However, growth of the treated cells of both bacterial pathogens in BHI broths treated by either $2 \%$ or $4 \% v / v$ KFB decreased significantly $(p \leq 0.05)$, and differences between values of $\log \mathrm{CFU} / \mathrm{mL}$ of controls and treated samples were almost $10 \log$ cycles after 48 and $72 \mathrm{~h}$ in all treatments. No growth of S. aureus and E. coli was detected after $48 \mathrm{~h}$ and $72 \mathrm{~h}$ of incubation, respectively, in BHI broths treated with $4 \%$ KFB. No growth of either of the bacterial pathogens was detected after $96 \mathrm{~h}$ of incubation in BHI broths treated with $2 \%$ KFB (Figure 3A,B).

In sterile apple juice treated with either $2 \%$ or $4 \% v / v$ KFB and inoculated with $7.3 \times 103 \mathrm{CFU} / \mathrm{mL}$ of either S. aureus or E. coli, the growth of the control cells of both S. aureus (Figure 4A) or E. coli (Figure 4B) increased vigorously, with an almost 7 log cycles increase within $96 \mathrm{~h}$. However, growth $(\mathrm{CFU} / \mathrm{mL})$ of the treated cells decreased significantly $(p \leq 0.05)$ and no growth was detected in either of the bacterial pathogens following $72 \mathrm{~h}$ of incubation in apple juice treated by $2 \%$ KFB. Treatment with $4 \%$ KFB showed no growth of S. aureus and E. coli after $24 \mathrm{~h}$ and $48 \mathrm{~h}$, respectively (Figure $4 \mathrm{~A}, \mathrm{~B}$ ).

The inhibitory effect of KFB $(2 \% \& 4 \%)$ on $S$. aureus and E. coli grown in fresh guava juice was investigated (Figure 5A,B). The control cells increased by almost 7 log cycles within $96 \mathrm{~h}$, but growth $(\mathrm{CFU} / \mathrm{mL})$ of the treated cells decreased significantly $(p \leq 0.5)$, and no growth of either bacterial strain was recorded after $48 \mathrm{~h}$ and $72 \mathrm{~h}$ in guava juice samples treated with $4 \% \mathrm{KFB}$, or after 72 and $96 \mathrm{~h}$ in samples treated with $2 \% \mathrm{KFB}$, respectively (Figure 5A,B). 


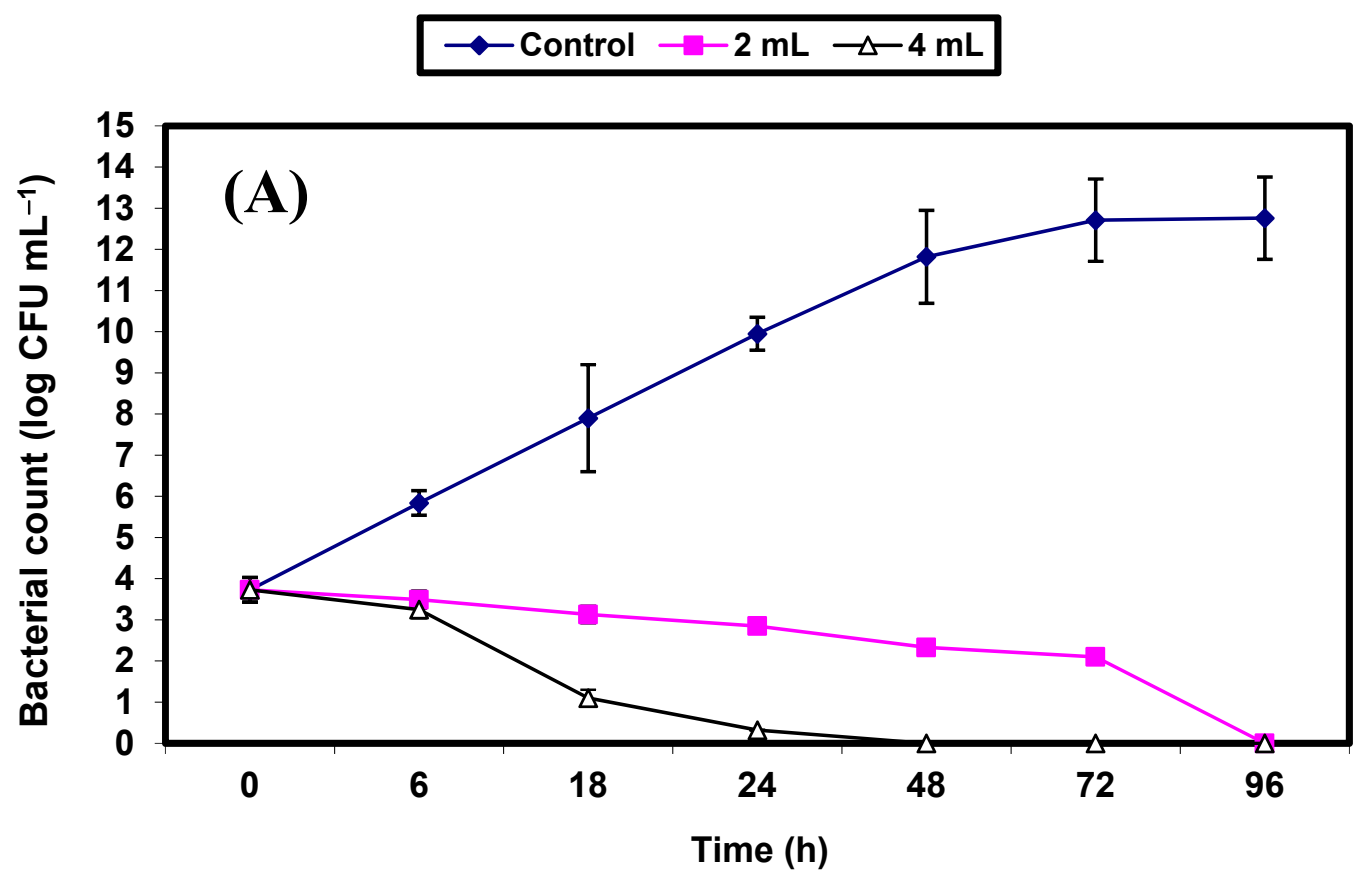

$\leftrightarrow$ Control $\rightarrow-2 \mathrm{~mL} \rightarrow 4 \mathrm{~mL}$

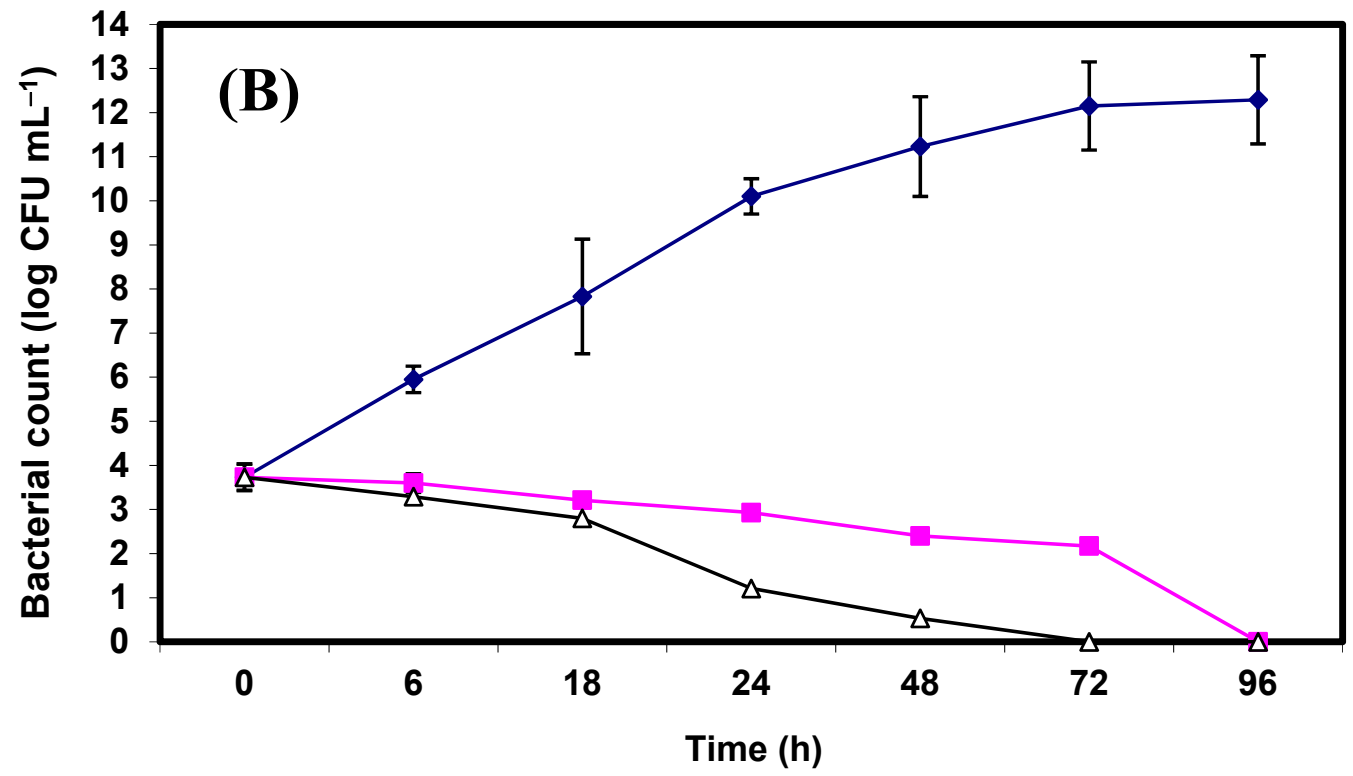

Figure 3. Inhibition of both S. aureus (A) and E. coli (B) in BHI broth. Symbols $\downarrow$; $\square$; $\Delta$ refer to untreated control samples and juice samples treated with $2 \%$ and $4 \% \mathrm{KFB}$, respectively. 

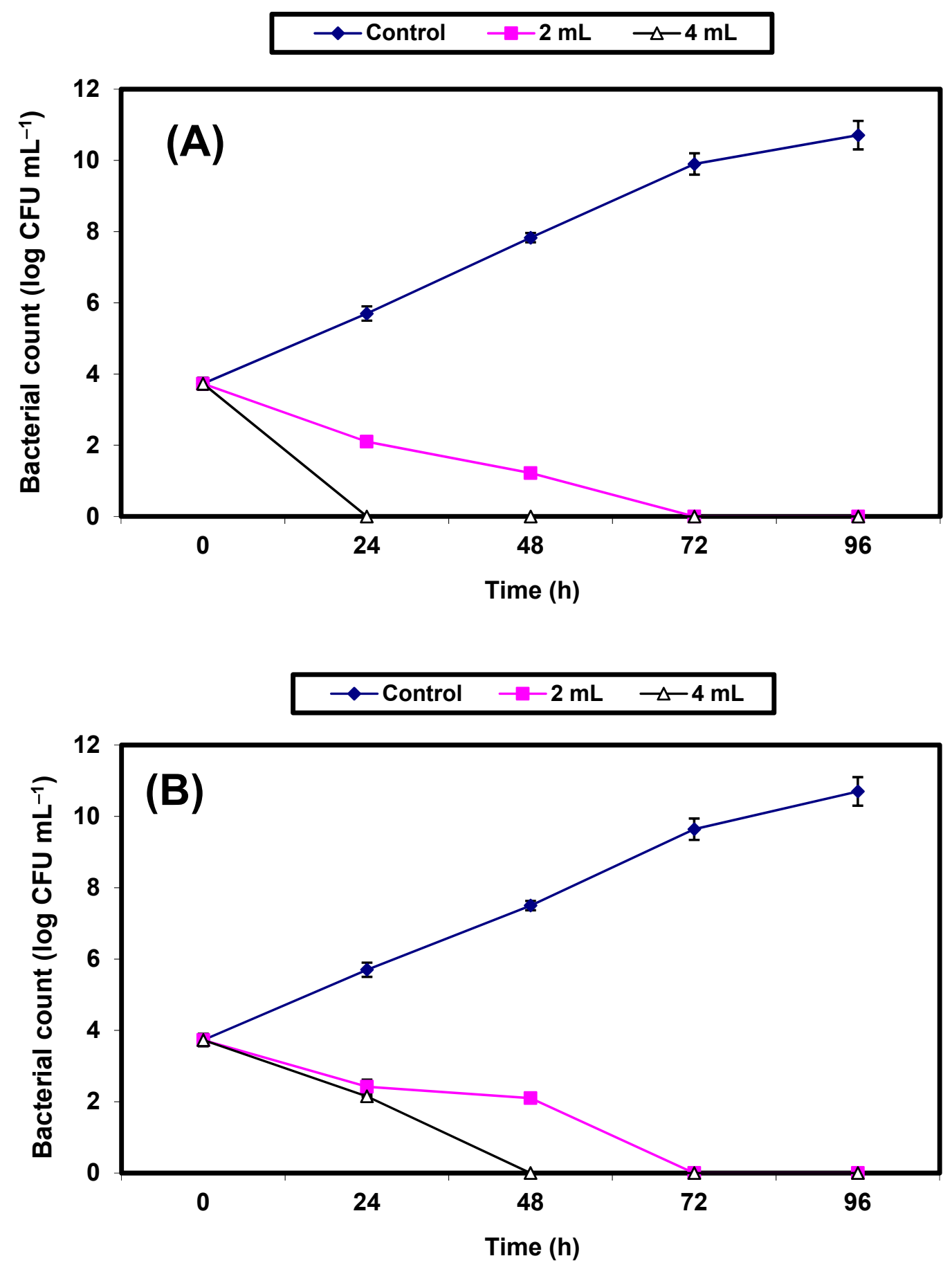

Figure 4. Inhibition of both S. aureus (A) and E. coli (B) in apple juice. Symbols $\downarrow, \square, \Delta$ refer to untreated control samples and juice samples treated with $2 \%$ and $4 \% \mathrm{KFB}$, respectively. 
$\multimap$ Control $\neg-2 \mathrm{~mL} \triangle-4 \mathrm{~mL}$

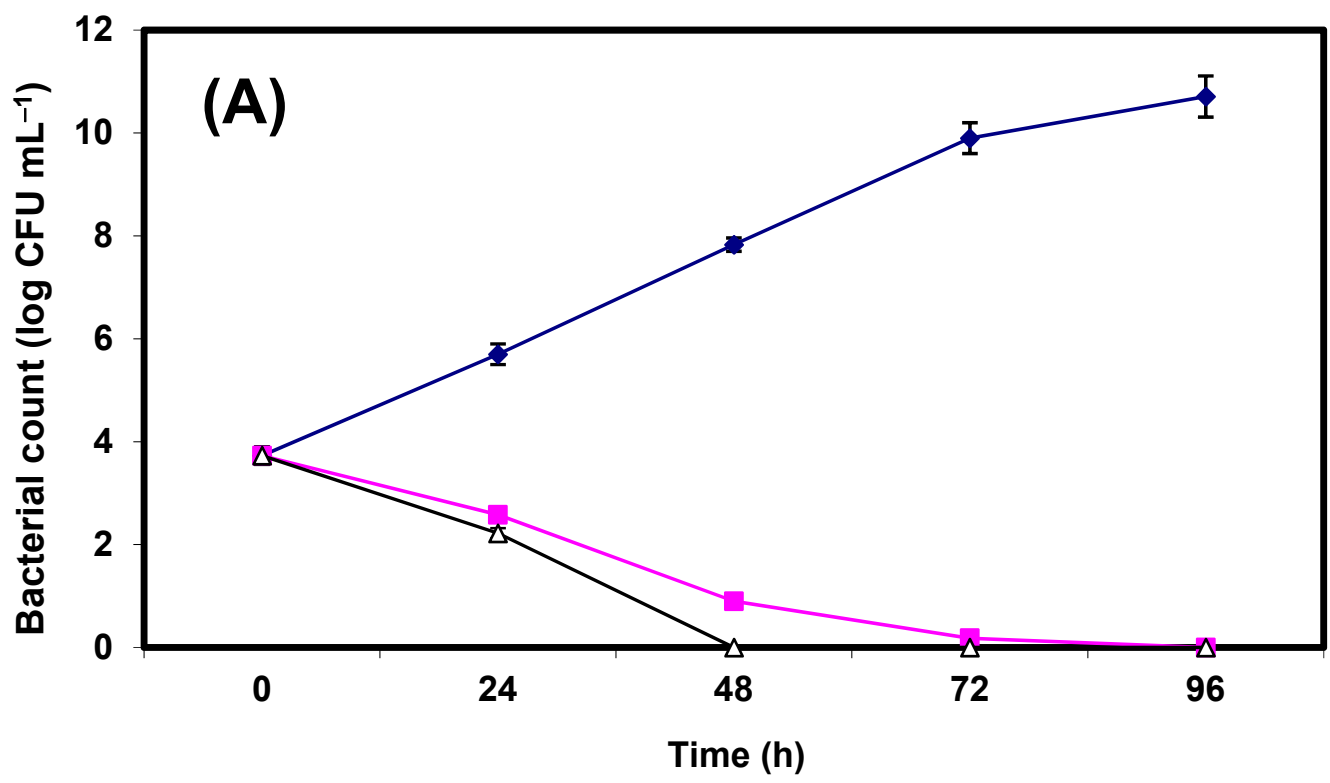

$\neg$ Control $\neg-2 \mathrm{~mL} \neg-4 \mathrm{~mL}$

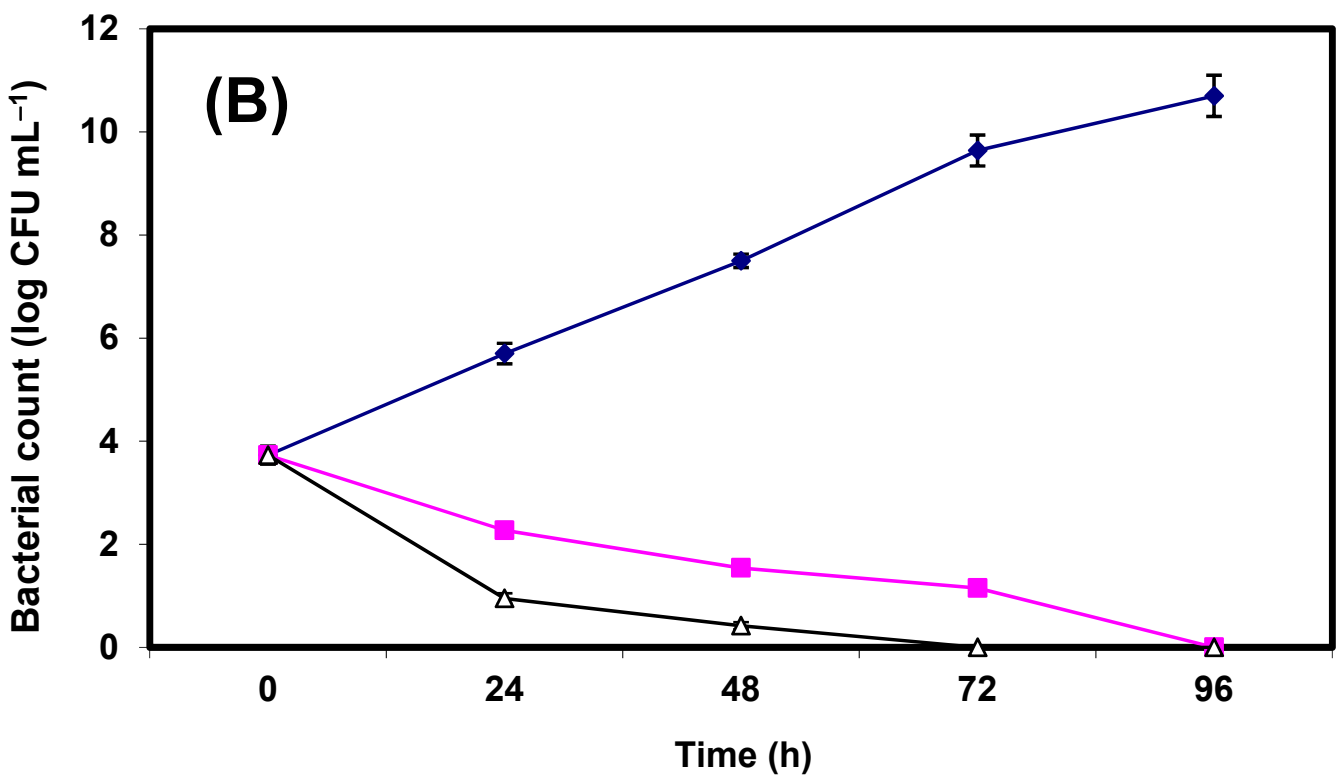

Figure 5. Inhibition of both S. aureus (A) and E. coli (B) in guava juice. Symbols $\downarrow, \square, \Delta$ refer to untreated control samples and juice samples treated with $2 \%$ and $4 \% \mathrm{KFB}$, respectively.

Results of the effect of $2 \%$ and $4 \%(v / v)$ KFB on the growth of the two pathogenic bacteria strains inoculated in sterile strawberry juice are given in Figure 6A,B. The growth of the control cells increased, reaching almost 7 log cycles within $96 \mathrm{~h}$ for both organisms, but the growth of both pathogens decreased significantly $(p \leq 0.05)$, reaching zero after $48 \mathrm{~h}$ of incubation in samples treated with $4 \%$ KFB. In juice samples treated with $2 \% \mathrm{KFB}$, no growth of either strain was detected after $72 \mathrm{~h}$ of incubation (Figure 6A,B). 

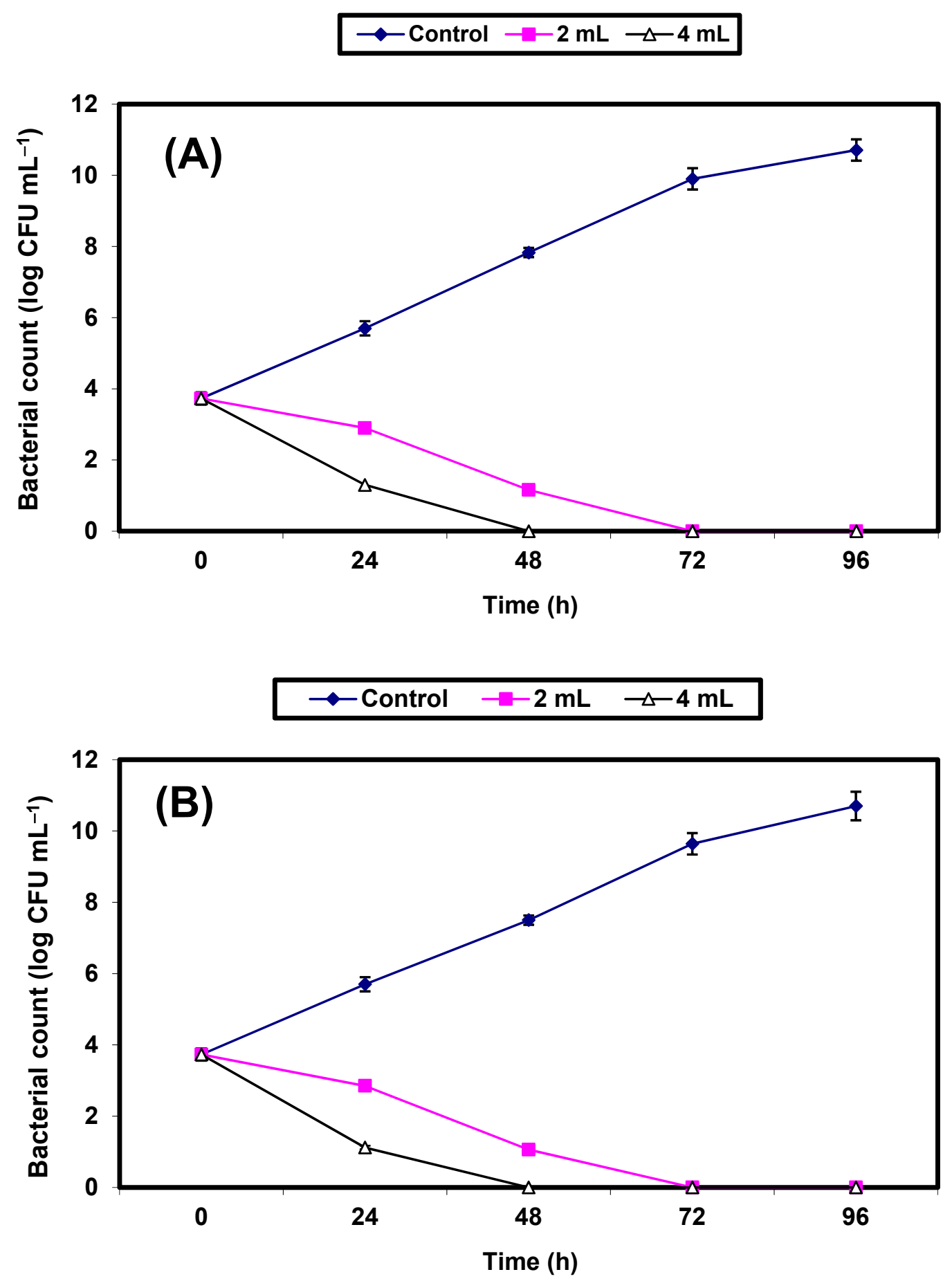

Figure 6. Inhibition of both S. aureus (A) and E. coli (B) in strawberry juice. Symbols $\downarrow, \square, \Delta$ refer to untreated control samples and juice samples treated with $2 \%$ and $4 \%$ KFB, respectively.

The inhibition of both S. aureus and E. coli in tomato juice by KFB (2\% and $4 \%)$ was studied. Results are given in Figure 7A,B. The control cells increased by almost 7 log cycles within $96 \mathrm{~h}$, but growth $(\mathrm{CFU} / \mathrm{mL})$ of the treated cells decreased distinctly $(p \leq 0.05)$, and no growth of $S$. aureus and E. coli was recorded after $48 \mathrm{~h}$ and $96 \mathrm{~h}$, respectively, in juice treated with $4 \%$ and $2 \% \mathrm{KFB}$, respectively (Figure $7 \mathrm{~A}, \mathrm{~B}$ ). 


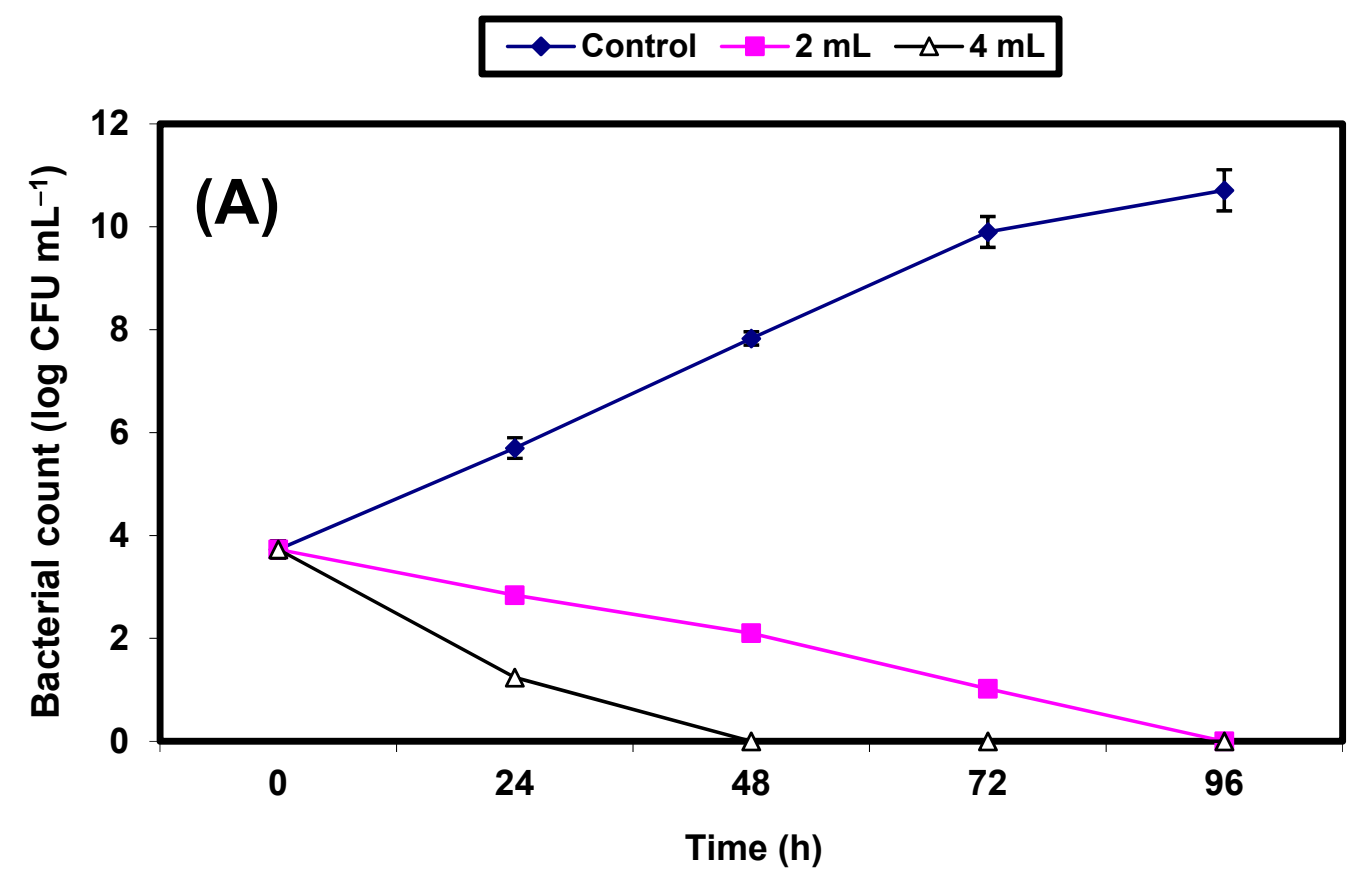

$\rightarrow-$ Control $\rightarrow-2 \mathrm{~mL} \rightarrow-4 \mathrm{~mL}$

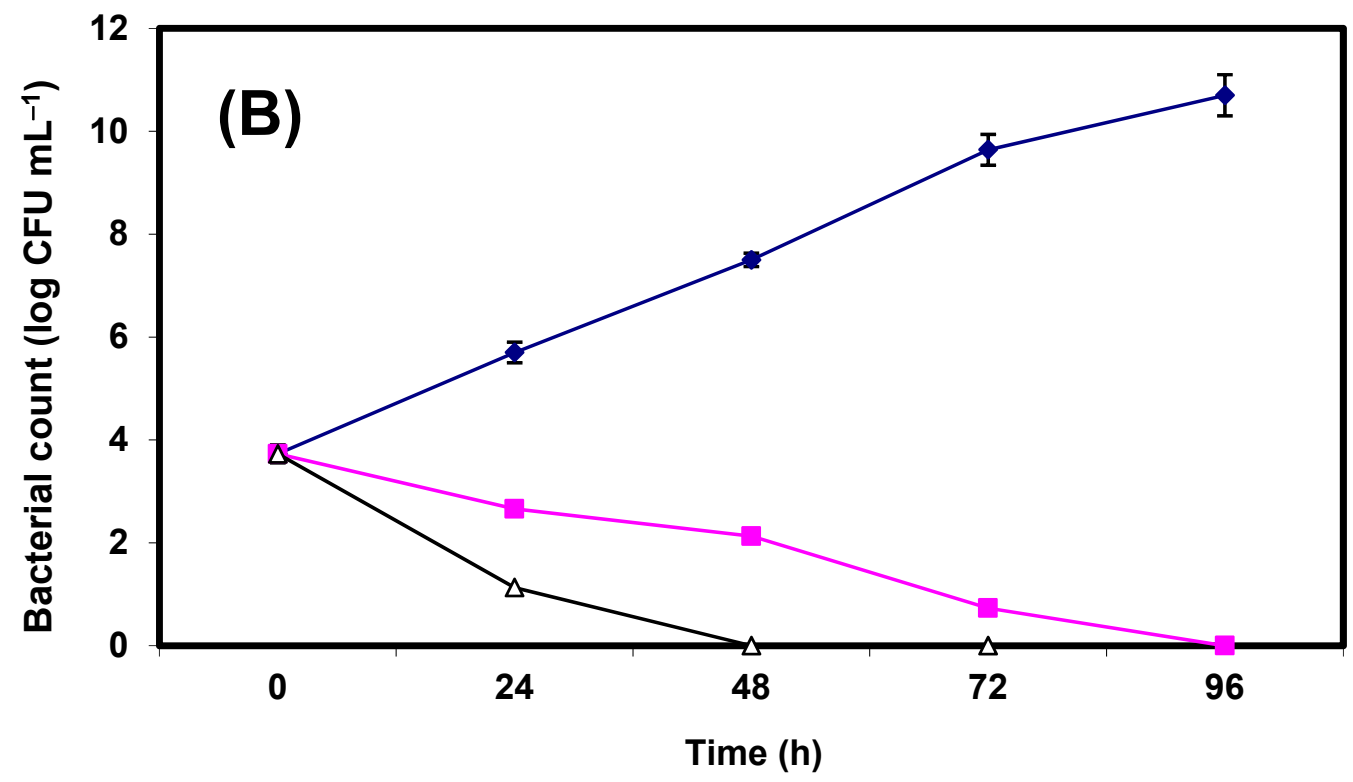

Figure 7. Inhibition of both S. aureus (A) and E. coli (B) in tomato juice. Symbols $\downarrow, \square, \Delta$ refer to untreated control samples and juice samples treated with $2 \%$ and $4 \% \mathrm{KFB}$, respectively.

\section{Discussion}

The kombucha used in this study was a traditional culture made by fermentation of black tea with kombucha mat (Egyptian made) [28]. Fermentation of kombucha results in the production of many fermentation end products. In this study, nine chemical groups were detected by GC-MS analysis; all of them were reported to inhibit bacterial pathogens by different mechanisms of action. However, it was found that the bioactive metabolites produced during the fermentation process of kombucha collectively have synergistic and cooperative effects [22]. 
Alkaloids have been reported to exert antibacterial activity by causing membrane damage and rapid denaturation of proteins, as well as nutrient leakage from the cell [29], thereby causing a defect in cell metabolism and cell lysis [30].

The esters and fatty acid esters detected herein were, in general, positively charged and more hydrophobic; such hydrophobicity allows electrostatic interactions with the bacterial cellular components, resulting in loss of cell viability via formation of fully deorganized killed cells. They also act as antibacterial food additives through the inhibition of bacterial growth and biofilm formation [10,31].

5-hydroxymethyl-2-furaldehyde (heterocyclic aldehyde) exhibited antibacterial activities against Gram-negative plant pathogenic bacteria; Xanthomonas axonopodis, Pectobacterium carotovorum subsp. atrosepticum, Pectobacterium chrysanthemi, Erwinia amylovora, and Herbaspirillum rubrisubalbicans [32]. The mechanism of antibacterial action of 5-nitro2-furaldehyde (a furaldehyde derivative) was reported through its interaction with DNA secondary to formation of a nitro anion radical via one-electron reduction of the redoxactive nitrofuran moiety [33]. Aromatic aldehydes detected in this study were reported to possess remarkable bactericidal activity through their binding with the outer layer of bacterial cells [34], specifically with unprotonated amines on the cell surface which in turn affect the transport of ions across the cell wall and on enzyme systems where access of substrate to an enzyme is prohibited [35].

Both unsaturated lactones and hydroxylactones detected herein KFB were found to exhibit antimicrobial activity against pathogenic strains of bacteria (Staphylococcus aureus, Pseudomonas fluorescens W1), yeasts (Candida albicans KL-1) and filamentous fungi (Alternaria sp., Penicillium sp.) [36]. The ability of lactone compounds to act as inhibitory substances against several microorganisms is due to their ability to penetrate the microbial cell and inactivate sulphydryl-containing enzymes necessary for cellular replication [37].

The antibacterial activity of heterocyclic compounds has been reported through their ability to interact with either electrophiles or nucleophiles of the cells, leading to the inhibition of cell wall synthesis, protein synthesis, DNA synthesis, metabolic pathways, and interference with cell membrane integrity [38].

The presence and quantity of the kombucha chemical constituents are variable, mainly depending on the microorganisms of the symbiotic culture used for fermentation of kombucha, as well as fermentation time and temperature, sucrose content and type of tea used, in addition to the analysis methods used for quantification [16,22].

In the current study, we isolated and identified bacterial isolates in the kombucha consortium. All bacterial identification was carried out automatically by Viteck-2 system (Vitek ${ }^{\circledR}$ 2: Healthcare I Biomérieux, Marcy-l'Étoile, France) for the accuracy portion of the study. Three bacterial isolates of acetic acid bacteria from kombucha were identified on acetobacter agar medium which are Acetobacter xylinum, A. pasteurians, and A. aceti. Additionally, two lactic acid bacterial isolates were identified in this study; Lactobacillus fermentum and L. acidophilus. In agreement with our study, Mayser et al. [39] and Sievers et al. [40] reported the isolation of A. xylinum from the kombucha consortium. In another study, Marsh et al. [41] reported that the dominant bacteria in five kombucha samples from different origins were species of Gluconacetobacter and Lactobacillus. The most abundant bacterial species in this culture belonged to the bacterial genera Acetobacter and Gluconobacter [16]. In addition to bacterial isolates, two yeasts isolates, Saccharomyces cerevisiae and Schizosaccharomyces pombe, were identified by API-yeasts kits. The bacterial and yeast species encountered from kombucha in this study almost concur with previous published studies $[16,22]$. Similarly to the milk-derived kefir, the exact microbial composition of kombucha varies according to some factors such as the type of fermented substrate, the source of starter culture, the duration of fermentation process $[10,16]$.

The data employed herein showed that the fermented preparation (KFB) from 14 days incubation of kombucha starter in black tea exerted the strongest antimicrobial activities. These activities were also exhibited after heating-treatment of kombucha beverage (HBK) but with a decrease in antibacterial and antifungal activity. The neutralized kombucha 
preparation (NKB) showed the lowest antimicrobial activities against the organisms tested. In support of the present study, Battikh et al. [23] demonstrated that fermented infusion of kombucha was superior in its antibacterial activity to unfermented, neutralized, acidified and heat-denatured infusion against pathogenic bacteria. They further showed that the heat-denatured preparation had more antibacterial activity against bacterial strains tested than the neutralized preparation. Several additional previous studies proved that kombucha of fermented black tea exerts antibacterial activity against a broad spectrum of bacteria [19,42-44]. Kaewkod et al. [45] found that the kombucha prepared from different types of tea (green, oolong and black) after 15 days of fermentation had efficient inhibitory activity on all pathogenic enteric bacteria tested: E. coli O157:H7 DMST 12743, Shigella dysenteriae DMST 1511, Salmonella typhi DMST 22842, and Vibrio cholerae.

A small number of studies in the literature have demonstrated the antifungal activity of kombucha. Sreeramulu et al. [20] reported that kombucha tea fermented for 6-14 days had antifungal activity against $C$. albicans. Battikh et al. [23] showed that fermented infusion of kombucha black tea for 21 days exhibited antifungal activity against C. glabrata, C. tropicalis, C. dubliniensis, and C. albicans. In a previous study, kombucha supernatant $(10 \%, v / v)$ made from black tea after fermentation for 14 days caused a complete mycelium growth inhibition of Acremonium implicatum LC015097 and reduced the mycelial growth of Penicillium expansum LC015096, Talaromyces purpureogenus LC015095, in addition, it inhibited the production of the mycotoxin patulin by three fungal strains [28].

The antimicrobial activity exhibited by the KFB and HBK preparations may be explained on the basis of the acidity of organic acids (acetic, citric and gluconic acids) in kombucha beverage [17]. These organic acids, produced during fermentation from conversion of sucrose by yeasts and bacteria present in the kombucha consortium, shift the $\mathrm{pH}$ to final levels around 2.5-3.0, as recorded herein. This is strongly supported by previous studies confirming that increased concentration of organic acids produced in fermented kombucha broth made the $\mathrm{pH}$ decreased from 5 to 2.5 [20,46]. Moreover, Greenwalt et al. [42] showed that the antimicrobial activity of kombucha against pathogenic microorganisms is largely attributable to acetic acid. Organic acid molecules could induce cytoplasmic acidification and destroy bacterial cells [45]. The antibacterial activity exerted by kombucha compounds might also be interpreted on the basis of osmotic pressure of the solutes which existed in the hypertonic medium in relation to the outer aquatic medium; this facilitates the diffusion of the bioactive materials from cell membranes via the selective permeability. The lipophilic nature of some solutes facilitates their attachment to bacterial cell membranes which in turn causes cell death $[47,48]$.

The lower antimicrobial potential of the NKB preparation compared to the KFB and HBK preparations implies that the inhibitory activity against bacterial and fungal strains was not due to acidic $\mathrm{pH}$ only, but also due to the other biological active compounds (proteins, antibiotics, alcohols, aldehydes, etc.) or metabolites other than acetic acid biosynthesized during the fermentation process of kombucha consortium. Such inhibitory biological compounds are heat sensitive, since the HKB preparation herein was tested as an alternative to KFB in order to characterize the nature of these compounds produced by kombucha. According to the present study, the inhibitory activity of kombucha infusions was not often due to heat-sensitive molecules; therefore, the antimicrobial activity of HKB preparation was either enhanced or reduced. This was clearly supported by Sreeramulu et al. [20] and Battikh et al. [23], and explained the weak antimicrobial activity exhibited by NKB preparation.

In all cases, S. aureus (a Gram-positive bacteria) and E. coli (a Gram-negative bacteria) were the most susceptible organisms for the antimicrobial activity of kombucha beverage preparations giving inhibition zones diameter of 19 and $18 \mathrm{~mm}$, respectively in this study. Using agar diffusion assay, Battikh et al. [23] found that kombucha tea showed lower inhibition zone diameters of the two respective bacterial species (14.5 and $11 \mathrm{~mm}$ ) than those obtained in this study. These data are very important, because both bacterial species are enteropathogenic microorganisms and are still the most prevalent and important public 
health problem in developing countries; in addition, they are the most common pathogens causing healthcare-associated infections and bacteremia and the treatment of their infections is becoming increasingly difficult due to emerging antimicrobial resistance [49-54].

In this study, S. aureus and E. coli were employed in further experiments concerned with the control of their contamination in BHI broth and juices such as apple juice, guava juice, strawberry juice, and tomato juice. Results obtained showed that KFB preparation significantly inhibited both bacterial strains in all trials. This is a promising result for the possibility of using KFB not only as a juice additive but also as a starter for obtaining protective syrup during vegetable or fruit juice fermentation. In a similar manner, Ayed et al. [55] developed a beverage from red grape juice fermented with the Kombucha consortium for 12 days that showed a remarkable antibacterial activity against $E$. coli ATCC 10536, P. aeruginosa ATCC 9027, K. pneumoniae ATCC 10031, S. aureus ATCC 6538, S. epidermidis ATCC 12228, Enterococcus faecalis ATCC 10541, and B. cereus ATCC 11778. The authors attributed the antibacterial activity was not due to polyphenolics, but rather to metabolites produced during fermentation such as acetic acid as well as other organic acids in KFB. In a previous study, KFB preparation was used efficiently for growth inhibition of Acremonium implicatum LC015097 (a strain causing decaying of apple fruits) and inhibition of mycotoxin patulin accumulation in liquid medium and apple fruits [28].

Finally, it is more advisable to use a safe probiotic drink like kombucha that contains several synergistic antimicrobial components than a single component that may be more expensive with a lower antimicrobial efficacy. This trend is promising and has applied feasibility within the functional food market. Therefore, GC-MS was used in this study as an analytical method that combines the features of gas-chromatography and mass spectrometry to identify different components within the KFB. Many volatile flavor compounds are produced during the fermentation of kombucha using black tea, and this is clearly supported by previous research [56], where 21 volatile flavor compounds were identified in the initial kombucha fermentation broth in raw tea and 56 volatile flavor compounds were identified after 10 days of fermentation [56]. Additionally, drying temperature, tea grade, and temperature-grade interaction showed a significant effect on the volatile composition of black tea [57].

\section{Materials and Methods}

\subsection{Kombucha Consortium}

The tea fungus starter culture used in this study, a traditionally Egyptian-made one, was a symbiotic culture between yeast and acetic acid bacteria producing a cellulosic pellicle layer floating on the surface of the fermented broth during the fermentation process of kombucha [28].

\subsection{Preparation of Kombucha Fermented Beverage (KFB)}

Kombucha fermented beverage (KFB) was prepared by adding $1.2 \%$ black tea (El Arosa Egyptian dust black tea) to boiling water in and left to infuse for about $5 \mathrm{~min}$, thereafter the infusion was filtered through sterile sieve. Sucrose $(10 \%)$ was dissolved in hot tea and the solution $(200 \mathrm{~mL})$ was left to cool, transferred into a sterile $500 \mathrm{~mL}$ glass vessel $(22 \times 20 \times 15 \mathrm{~cm})$. The preparation was inoculated with $3 \%(w / v)$ of freshly grown tea fungus that had been cultured in the same fermentation medium for 14 days and $10 \%(v / v)$ of previously fermented kombucha beverage asceptically. The glass vessel was carefully covered with a clean cloth and incubated at $30^{\circ} \mathrm{C}$ for about 14 days in the dark to avoid oxidation of phenolic compounds [58]. The obtained kombucha beverage was filtered to remove the cellulose pellicle, and the supernatant was subjected immediately to both chemical and microbiological analysis. The obtained KFB aliquots used in the antimicrobial tests were stored in the refrigerator at $4{ }^{\circ} \mathrm{C}$ until used. After storage for a week, the KFB aliquots were surface-sterilized before applying the antimicrobial potency tests. 


\section{3. $p H$ Determination}

The $\mathrm{pH}$ of KFB was measured using an electronic $\mathrm{pH}$ meter (Denver Instruments, Bohemia, NY, USA).

\subsection{Instrumental Analysis of KFB}

The analysis of KFB existing chemical compounds was performed using Trace GC 1310-ISQ mass spectrometer (Thermo Scientific, Austin, TX, USA) with a direct capillary column TG-5 MS ( $30 \mathrm{~m} \times 0.25 \mathrm{~mm} \times 0.25 \mu \mathrm{m}$ film thickness). The column oven temperature was initially held at $50^{\circ} \mathrm{C}$ and then increased by $5^{\circ} \mathrm{C} / \mathrm{min}$ to $230^{\circ} \mathrm{C}$ for $2 \mathrm{~min}$ and increased to the final temperature $290^{\circ} \mathrm{C}$ at a rate of $30^{\circ} \mathrm{C} / \mathrm{min}$ and hold for $2 \mathrm{~min}$. The injector and MS transfer line temperatures were kept at $250,260^{\circ} \mathrm{C}$, respectively; helium was used as a carrier gas at a constant flow rate of $1 \mathrm{~mL} / \mathrm{min}$. The solvent delay was $3 \mathrm{~min}$ and the kombucha tea samples were filtered through a $0.22 \mu \mathrm{m}$ sterile microfilter and $50 \mu \mathrm{L}$ of the filtrate was injected automatically using Auto sampler AS 1300 coupled with GC in the split mode. The mass spectra were collected at $70 \mathrm{eV}$ ionization voltages over the range of $\mathrm{m} / \mathrm{z}$ $40-1000$ in full scan mode. The ion source temperature was set at $200^{\circ} \mathrm{C}$. Compounds were identified by comparison of their retention times and mass spectra with those of WILEY 09 and the National Institute of Standards and Technology 2011 mass spectral library (NIST 11) $[59,60]$.

Infrared spectra of the obtained KFB were measured with a Fourier transform infrared (FTIR) spectrometer (Bruker Optik GmbH, Ettlingen, Germany) according to the method reported by previous researches $[61,62]$, to determine the presence of various functional groups in the obtained KB. The pellets for FTIR analysis were obtained by grinding a mixture of $1 \mathrm{mg}$ of freeze-dried KB powder with $100 \mathrm{mg}$ of dry potassium bromide powder $(\mathrm{KBr})$, followed by pressing the mixture in a mold. The FT-IR spectra were recorded in the region of $4000-400 \mathrm{~cm}^{-1}$ at a resolution of $4 \mathrm{~cm}^{-1}$. The resulting data were processed using OPUS/IR NT4.0 spectroscopic software package (Bruker Optik GmbH) installed on the FTIR instrumentation.

\subsection{Isolation and Identification of Bacterial Species from the Kombucha}

Serial two-fold dilutions of the KFB were made; then $0.1 \mathrm{~mL}$ aliquots from these dilutions were pipetted onto specific Acetobacter agar (Oxoid, Basingstoke, UK); MRS agar plates [63,64]; Sabaraoud agar (Oxoid) for isolation of acetic acid bacteria; lactic acid bacteria; yeasts respectively. The agar plates were incubated at $35^{\circ} \mathrm{C}$ for either $48 \mathrm{~h}$ for bacteria or 4 days for yeasts. Pure and single colonies of the obtained microbes were picked up by sterile needles and inoculated into Brain Heart Infusion broths (BHI broth, Oxoid). After $24 \mathrm{~h}$ of incubation at $35^{\circ} \mathrm{C}$, bacterial identification was carried out automatically by Vitek 2 system (Vitek ${ }^{\circledR}$ 2: Healthcare I Biomérieux, France). The isolated bacterial species were checked for their Gram stain and cell morphology using a light microscope [65]. Yeasts were identified via morphological examination under light microscope and API-yeasts kits (BioMérieux, France) as given by the manufacturer's instructions [66].

\subsection{Microbial Test Strains}

The microbial strains used in the antimicrobial tests included both bacterial and fungal pathogens. The bacterial strains used included Gram-positive bacteria such as Staphylococcus aureus ATCC6538 (S. aureus), Bacillus cereus ATCC14579 (B. cereus), Listeria monocytogenes ATCC4957 (L. monocytogenes), and Gram-negative bacteria such as Escherichia coli ATCC11229 (E. coli) and Salmonella typhimurium ATCC14028 (Sal. typhimurium). These bacterial test strains were maintained in glass beads, stored at $-20^{\circ} \mathrm{C}$, and subcultured into brain heart infusion broth (BHI broth, Oxoid). The fungal test strains used, included Aspergillus flavus ATCC16872 (A. flavus) and Aspergillus niger ATCC20611 (A. niger). These fungal cultures were stored at $-20^{\circ} \mathrm{C}$ and subcultured onto potato dextrose broth (Difco, Sparks, NV, USA). 


\subsection{Antimicrobial Bioassays of Kombucha Beverage}

The KFB was prepared as described above. It was also neutralized (NKB) at $\mathrm{pH} 7.0$ by adjusting the $\mathrm{pH}$ with $1 \mathrm{M} \mathrm{HCl}$ or $1 \mathrm{M} \mathrm{NaOH}$. Heat-denatured kombucha (HKB) was prepared by treatment of $\mathrm{KFB}$ at $120{ }^{\circ} \mathrm{C}$ for $15 \mathrm{~min}$. The prepared kombucha samples were all centrifuged at $15,000 \mathrm{rpm}$ for $15 \mathrm{~min}$ to remove cell debris. Sterile supernatants were obtained by filtering the supernatants through a sterile microfilter (Millex-GV filter, $0.22 \mu \mathrm{m}$ pore size, Millipore, Burlington, MA, USA). The antimicrobial activities of all kombucha samples were studied using an agar well diffusion assay [67]. Brain Heart infusion agar plates (BHI agar, Oxoid) were prepared and inoculated by $7.3 \times 10^{3} \mathrm{CFU} / \mathrm{mL}$ of the bacterial strains tested. Additionally, potato dextrose agar plates (PDA, Oxoid) were prepared and inoculated by $10^{7}$ spores $/ \mathrm{mL}$ of the fungal strains tested. Microbial inocula were spread onto the agar plates by sterile glass rods under completely aseptic conditions. Wells of $10 \mathrm{~mm}$ diameter were made with a sterile cork borer. Sterile samples $(100 \mu \mathrm{L})$ were then transferred into the wells of agar plates inoculated with tested strains. The plates were first stored at $4{ }^{\circ} \mathrm{C}$ for $2 \mathrm{~h}$ to allow a pre-diffusion of the kombucha preparation into the agar and treated agar plates were incubated at $35^{\circ} \mathrm{C}$ for $48 \mathrm{~h}$ in the case of the bacterial strains and 5 days for fungal strains tested. Diameters of inhibition zones were then measured according to Clinical and Laboratory Standards Institute (CLSI) [68].

\subsection{Preparation of Fruit Juices Employed in the Antimicrobial Activity of KFB}

Fresh fruits of apple (Malus domestica), guava (Psidium guajava), strawberry (Fragaria ananassa) and tomato (Solanum lycopersicum) were purchased from local markets located in Zagazig City, Sharkia Governorate ( $80 \mathrm{Km}$ north Cairo), Egypt.

Fresh fruits were washed with sterile distilled water. One hundred grams of each fruit sample were mixed with distilled water at the ratio of $1: 1(w / v)$ as described previously [69,70], then homogenized by using a mixer (Braun combimax 700 vital, Berlin, Germany). The obtained fresh juice was then centrifuged at 15,000 rpm for $30 \mathrm{~min}$ at room temperature. The supernatant of each fresh juice was collected in glass bottles, sterilized by autoclaving at $15^{\circ} \mathrm{C}$ for $15 \mathrm{~min}$ and was then cooled and stored in refrigerator at $4{ }^{\circ} \mathrm{C}$ until used.

4.9. Inhibition of Both E. coli and S. aureus in BHI Broth and Juices of Apple, Guava, Strawberry and Tomato

A series of 250-mL Erlenmeyer flasks; each containing $100 \mathrm{~mL}$ aliquots of either BHI broth (Oxoid) or fruit juices were sterilized by autoclaving at $120^{\circ} \mathrm{C}$ for $15 \mathrm{~min}$. After cooling, they were separately inoculated with $7.3 \times 10^{3} \mathrm{CFU} / \mathrm{mL}$ of either E. coli or S. aureus, treated by either $2 \%$ or $4 \% \mathrm{KFB}$, and were then incubated in an incubator (New Brunswick Scien. Co., North Brunswick, NJ, USA) at $30{ }^{\circ} \mathrm{C}$ for 4 days. Every $24 \mathrm{~h}$, samples were withdrawn and the growth of the indicator bacteria $(\mathrm{CFU} / \mathrm{mL})$ was calculated as described previously [67].

\subsection{Statistical Analysis}

Results were expressed as the mean \pm standard deviation (SD). Statistical significance was evaluated using analysis of variance (ANOVA) test (SAS version 9.1, SAS Institute, Inc., Cary, NC, USA) [71] followed by the least significant difference (LSD) test at 0.05 level $(p<0.05$ means significant) [72].

\section{Conclusions}

In this study, the KFB was chemically analyzed by GC-MS and IR spectra, which was shown to contain nine chemical groups. These metabolites produced during the fermentation process collectively appeared to be responsible for the antimicrobial activity of kombucha in a synergistic action. KFB preparation exhibited a remarkable antimicrobial activity against some pathogenic bacteria and fungal strains using agar well diffusion technique and it was superior in its activity when compared with NKB and HKB preparation. 
This study offered new insights on application of KFB as safe alternative biopreservative for protection against pathogenic bacteria in fruit juices.

Author Contributions: G.E., A.A.I., A.A.Z. and A.-R.A.-M. proposed the research protocol, designed the experiments; G.E. and A.A.I. critically supervised the whole work and revised the manuscript; R.A.I. carried out the experiments; A.H.M. explained the GC-MS and IR spectra. All authors have read and agreed to the published version of the manuscript.

Funding: King Khalid Military Academy, Riyadh 11459, Saudi Arabia are responsible to pay the publication fees.

Institutional Review Board Statement: Not applicable.

Informed Consent Statement: Not applicable.

Data Availability Statement: The data presented in this study are available in the article.

Acknowledgments: The authors are indebted to Zagazig University, Egypt for practical facilities and to King Khalid Military Academy for financial support of the publication fees.

Conflicts of Interest: The authors declare that they have no conflict of interest.

Sample Availability: Samples are available from the authors.

\section{References}

1. Bermudez-Brito, M.; Plaza-Díaz, J.; Muñoz-Quezada, S.; Gómez-Llorente, C.; Gil, A. Probiotic mechanisms of action. Ann. Nutr. Metab. 2012, 61, 160-174. [CrossRef]

2. Enan, G.; Abdel-Shafi, S.; Ouda, S.M.; El-Balat, I. Genetic linkage of the antibiotic resistance ability in the Escherichia coli UR4 strain isolated from urine. J. Med. Sci. 2013, 13, 261-268. [CrossRef]

3. Enan, G.; El-Essawy, A.A.; Uyttendaele, M.; Debevere, J. Antibacterial activity of Lactobacillus plantarum UG1 isolated from dry sausage: Characterization, production and bactericidal action of plantaricin UG1. Int. J. Food Microbiol. 1996, 30, 189-215. [CrossRef]

4. Enan, G.; Abdel-Shafi, S.; Abdel-Haliem, M.F.; Negm, S. Characterization of probiotic lactic acid bacteria to be used as starter and protective cultures for dairy fermentations. Int. J. Probiotics Prebiotics 2013, 8, 157-163.

5. Enan, G.; Abdel-Shafi, S.; Ouda, S.; Negm, S. Novel antibacterial activity of Lactococcus lactis subsp. Lactis Z11 isolated from zabady. Int. J. Biomed. Sci. 2013, 9, 174-180. [PubMed]

6. Enan, G.; Osman, M.E.; Abdel-Haliem, M.E.F.; Abdel-Ghany, S.E. Advances in microbial and nucleic acids biotechnology. BioMed Res. Int. 2018, 2018, 3102374. [CrossRef] [PubMed]

7. Abdel-Shafi, S.; Al-Mohammadi, A.-R.; Negm, S.; Enan, G. Antibacterial activity of Lactobacillus delbreukii subspecies bulgaricus isolated from Zabady. Life Sci. J. 2014, 11, 264-270.

8. Ouda, S.M.; Debevere, J.; Enan, G. Purification and biochemical characterization of plantiricin UG1: A bacteriocin produced by Lactobacillus plantarum UG1 isolated from dry sausage. Life Sci. J. 2014, 11, 271-279.

9. Ivanišová, E.; Meňhartová, K.; Terentjeva, M.; Harangozo, L'.; Kántor, A.; Kántor, M. The evaluation of chemical, antioxidant, antimicrobial and sensory properties of kombucha tea beverage. J. Food Sci. Technol. 2020, 57, 1840-1846. [CrossRef]

10. Al-Mohammadi, A.-R.; Ibrahim, R.A.; Moustafa, A.H.; Ismaiel, A.A.; Abou Zeid, A.; Enan, G. Chemical constitution and antimicrobial activity of kefir fermented beverage. Molecules 2021, 26, 2635. [CrossRef]

11. Enan, G. Control of the regrowing bacteriocin resistant variants of Listeria monocytogenes LMG 10470 in vitro and in food by nisinplantaricin UG1 mixture. Biotechnology 2006, 5, 143-147. [CrossRef]

12. Ismaiel, A.A.; Ali, A.E.-S.; Enan, G. Incidence of Listeria in Egyptian meat and dairy samples. Food Sci. Biotechnol. 2014, 23, 179-185. [CrossRef]

13. Osman, A.; El-Didamony, G.; Sitohy, M.; Khalifa, M.; Enan, G. Soybean glycinin basic subunit inhibits methicillin resistant vancomycin intermediate Staphylococcus aureus (MRSA-VISA) in vitro. Int. J. Appl. Res. Nat. Prod. 2016, 9, 17-26.

14. McFarland, L.V. Meta-analysis of probiotics for the prevention of antibiotic associated diarrhea and the treatment of Clostridium difficile disease. Am. J. Gastroenterol. 2006, 101, 812-822. [CrossRef]

15. Gaziano, R.; Sabbatini, S.; Roselletti, E.; Perito, S.; Monari, C. Saccharomyces cerevisiae-based probiotics as novel antimicrobial agents to prevent and treat vaginal infections. Front. Microbiol. 2020, 11, 718. [CrossRef]

16. Jayabalan, R.; Malbaša, R.V.; Lončar, E.S.; Vitas, J.S.; Sathishkumar, M. A review on kombucha tea-microbiology, composition, fermentation, beneficial effects, toxicity, and "tea fungus". Compr. Rev. Food Sci. Food Saf. 2014, 13, 538-550. [CrossRef]

17. Villarreal-Soto, S.A.; Bouajila, J.; Souchard, J.; Taillandier, P. Understanding kombucha tea fermentation: A Review. J. Food Sci. 2018, 83, 580-588. [CrossRef] [PubMed] 
18. Kasper, Ed LAC. “The 3rd. Congress of Alternative Medicine and Acupuncture, Kombucha and AIDS Guadalajara Jalisco, México (11/98)". Happy Herbalist Web Site. Available online: http:/ / www.happyherbalist.com/kombucha.htm (accessed on 1 January 2009).

19. Greenwalt, C.J.; Steinkraus, K.H.; Ledford, R.A. Kombucha, the fermented tea: Microbiology, composition, and claimed health effects. J. Food Prot. 2000, 63, 976-981. [CrossRef] [PubMed]

20. Sreeramulu, G.; Zhu, Y.; Knol, W. Kombucha fermentation and its antimicrobial activity. J. Agric. Food Chem. 2000, 48, 2589-2594. [CrossRef] [PubMed]

21. Hartmann, A.M.; Burleson, L.E.; Holmes, A.K.; Geist, C.R. Effects of chronic kombucha ingestion on open-field behaviors, longevity, appetitive behaviors, and organs in C57-BL/6 mice: A pilot study. Nutrition 2000, 16, 755-761. [CrossRef]

22. Leal, J.M.; Suárez, L.V.; Jayabalan, R.; Oros, J.H.; Escalante-Aburto, A. A review on health benefits of kombucha nutritional compounds and metabolites. CyTA J. Food 2018, 16, 390-399. [CrossRef]

23. Battikh, H.; Bakhrouf, A.; Ammar, E. Antimicrobial effect of Kombucha analogues. LWT Food Sci. Technol. 2012, 47, 71-77. [CrossRef]

24. Watawana, M.I.; Jayawardena, N.; Gunawardhana, C.B.; Waisundara, V.Y. Health, wellness, and safety aspects of the consumption of kombucha. J. Chem. 2015, 11, 1-11. [CrossRef]

25. Enan, G.; Al-Mohammadi, A.-R.; El-Didamony, C.; Abdel-Haliem, M.E.F.; Zakaria, A. Antimicrobial activity of Enterococcus faecium NM2 isolated from urine: Purification, Characterization and bacterial action of enterocin NM2. Asian J. Appl. Sci. 2014, 7, 621-634. [CrossRef]

26. Enan, G.; Abdel-Haliem, M.E.F.; Tartour, E. Evaluation of the antimicrobial activity, starter capability and technological properties of some probiotic bacteria isolated from Egyptian pickles. Life Sci. J. 2014, 11, 976-985.

27. Prado, F.C.; Parada, J.; Pandey, A.; Soccol, C.R. Trends in non-dairy probiotic beverages. Food Res. Int. 2008, 41, 111-123. [CrossRef]

28. Ismaiel, A.A.; Bassyouni, R.H.; Kamel, Z.; Gabr, S.M. Detoxification of patulin by kombucha tea culture. CyTA J. Food 2016, 14, 271-279. [CrossRef]

29. The, J.S. Toxicity of short-chain fatty acids and alcohols towards Cladosporium resinae. Appl. Microbiol. 1974, 28, 840-844. [CrossRef]

30. Mithöfer, A.; Boland, W. Plant defense against herbivores: Chemical aspects. Annu. Rev. Plant Biol. 2012, 63, 431-450. [CrossRef]

31. Zhao, L.; Zhang, H.; Hao, T.; Li, S. In vitro antibacterial activities and mechanism of sugar fatty acid esters against five food-related bacteria. Food Chem. 2015, 187, 370-377. [CrossRef]

32. Espinoza, C.; Viniegra-González, G.; Loera, O.; Heredia, G.; Trigos, Á. Antibacterial activity against plant pathogens by cruded extracts and compounds from Idriella sp. Rev. Mex. Micol. 2008, 26, 9-15.

33. Holtzman, J.L.; Crankshaw, D.L.; Peterson, F.J.; Polnaszek, C.F. The kinetics of the aerobic reduction on nitrofurantoin by NADPH-cytochrome P-450(c) reductase. Mol. Pharmacal. 1981, 20, 669-673.

34. Beale, J.M.; Block, J.H. Wilson and Gisvold's Textbook of Organic Medicinal and Pharmaceutical Chemistry, 12th ed.; A Wolters Kluwer Business; Lippincot \& Wilkins: Philadelphia, PA, USA, 2011; ISBN 13-978-1609133986.

35. Trombetta, D.; Bisignano, G.; Arena, S. Study on the mechanisms of the antibacterial action of some plant $\alpha$ - $\beta$ - unsaturated aldehydes. Lett. Appl. Microbiol. 2002, 35, 285-290. [CrossRef]

36. Wińska, K.; Grabarczyk, M.; Maczka, W.; Zarowska, B.; Maciejewska, G.; Anioł, M. Antimicrobial activity of new bicyclic lactones with three or four methyl groups obtained both synthetically and biosynthetically. J. Saudi Chem. Soc. 2016, 22, 363-371. [CrossRef]

37. Mares, D. Antimicrobial activity of protoanemonin, a lactose from ranunculaceous plants. Mycopathologia 1987, 98, 133-140. [CrossRef]

38. Atia, A.J.K. Synthesis and antibacterial activities of new metronidazole and imidazole derivatives. Molecules 2009, 14, 2431-2446. [CrossRef]

39. Mayser, P.; Fromme, S.; Leitzmann, C.; Gründer, K. The yeast spectrum of the "tea fungus kombucha". Mycoses 1995, 38, 289-295. [CrossRef]

40. Sievers, M.; Lanini, C.; Weber, A.; Schuler-Schmid, U.; Teuber, M. Microbiology and fermentation balance in a kombucha beverage obtained from a tea fungus fermentation. Syst. Appl. Microbiol. 1995, 18, 590-594. [CrossRef]

41. Marsh, A.J.; O'Sullivan, O.; Hill, C.; Ross, R.P.; Cotter, P.D. Sequence-based analysis of the bacterial and fungal compositions of multiple Kombucha (tea fungus) samples. Food Microbiol. 2014, 38, 171-178. [CrossRef] [PubMed]

42. Greenwalt, C.J.; Ledford, R.A.; Steinkraus, K.H. Determination and characterization of the antimicrobial activity of the fermented tea kombucha. Lebensm. Wiss. Technol. 1998, 31, 291-296. [CrossRef]

43. Sreeramulu, G.; Zhu, Y.; Knol, W. Characterization of antimicrobial activity in kombucha fermentation. Acta Biotechnol. 2001, 21, 49-56. [CrossRef]

44. Steinkraus, K.H.; Shapiro, K.B.; Hotchkiss, J.H.; Mortlock, R.P. Investigations into the antibiotic activity of tea Fungus /Kombucha beverage. Acta Biotechnol. 1996, 16, 199-205. [CrossRef]

45. Kaewkod, T.; Bovonsombut, S.; Tragoolpua, Y. Efficacy of Kombucha obtained from green, oolong, and black teas on inhibition of pathogenic bacteria, antioxidation, and toxicity on colorectal cancer cell line. Microorganisms 2019, 7, 700. [CrossRef] [PubMed]

46. Lončar, E.; Djurić, M.; Malbaša, R.; Kolarov, L.J.; Klašnja, M. Influence of working conditions upon Kombucha conducted fermentation of black tea. Food Bioprod. Process. 2006, 84, 186-192. [CrossRef] 
47. Osman, A.; Abdel-Shafi, S.; Al-Mohammadi, A.-R.; Enan, G.; Sitohy, M. Catfish glycoprotein, a highly powerful safe preservative of minced beef stored at $4{ }^{\circ} \mathrm{C}$ for 15 days. Foods 2020, 9, 1115. [CrossRef] [PubMed]

48. Osman, A.; Bin-Jumah, M.; Abd El-Hack, M.; Elaraby, G.; Swelum, A.A.; Taha, A.E.; Sitohy, M.; Allam, A.A.; Ashour, E.A. Dietary supplementation of soybean glycinin can alter the growth, carcases traits, blood biochemical indices, and meat quality of broilers. Poult. Sci. 2020, 99, 820-828. [CrossRef] [PubMed]

49. Abdel-Shafi, S.; Osman, A.; Enan, G.; El-Nemer, M.; Sitohy, M. Antibacterial activity of methylated egg white proteins against pathogenic G+ and G- bacteria matching antibiotics. SpringerPlus 2016, 5, 983. [CrossRef]

50. Abdel-Shafi, S.; Al-Mohammadi, A.R.; Almanaa, T.N.; Moustafa, A.H.; Saad, T.M.M.; Ghonemy, A.; Anacarso, I.; Enan, G.; El-Gazzar, N. Identification and testing antidermatophyticoxaborole-6-derivative (OXBS) from Streptomyces atrovirens KM192347 isolated from soil. Antibiotics 2020, 9, 176. [CrossRef]

51. Abdel-Shafi, S.; Osman, A.; Al-Mohammadi, A.-R.; Kamal, N.; Sitohy, M. Biochemical, biological characteristics and antibacterial activity of glycoprotein extracted from the epidermal mucus of African catfish (Clarias gariepinus). Int. J. Biol. Macromol. 2019, 138, 773-780. [CrossRef]

52. El-Gazzar, N.S.; Enan, G. Advances in phage inspired nanoscience based therapy. In Nanobioscience; Saxena, S.K., Khurana, S.P., Eds.; Springer Nature Singapore Pte Ltd.: Singapore, 2020; pp. 237-257. ISBN 978-981-32-9898-9_10.

53. Poolman, J.T.; Anderson, A.S. Escherichia coli and Staphylococcus aureus: Leading bacterial pathogens of healthcare associated infections and bacteremia in older-Age populations. Expert Rev. Vaccines 2018, 17, 607-618. [CrossRef]

54. Enan, G.; Al-Mohammadi, A.-R.; Mahgoub, S.; Abdel-Shafi, S.; Askar, E.; Ghaly, M.F.; Taha, M.A.; El-Gazzar, N. Inhibition of Staphylococcus aureus LC554891 by Moringa oleifera seed extract either singly or in combination with antibiotics. Molecules 2020, 25, 4583. [CrossRef]

55. Ayed, L.; Ben Abid, S.; Hamdi, M. Development of a beverage from red grape juice fermented with the kombucha consortium. Ann. Microbiol. 2017, 67, 111-121. [CrossRef]

56. Zhao, Z.; Sui, Y.; Wu, H.; Zhou, C.; Hu, X.; Zhang, J. Flavour chemical dynamics during fermentation of kombucha tea. Emir. J. Food Agric. 2018, 30, 732-741.

57. Polat, A.; Sat, I.G.; IIgaz, S. Comparison of black tea volatiles depending on the grades and different drying temperatures. J. Food Process. Preserv. 2018, 42, e13653. [CrossRef]

58. Jayabalan, R.; Marimuthu, S.; Thangaraj, P.; Sathishkumar, M.; Binupriya, A.R.; Swaminathan, K.; Yun, S.E. Preservation of kombucha tea-effect of temperature on tea components and free radical scavenging properties. J. Agric. Food Chem. 2008, 56, 9064-9071. [CrossRef] [PubMed]

59. El-Gazzar, N.; Almaary, K.; Ismail, A.; Polizzi, G. Influence of Funneliformis mosseae enhanced with titanium dioxide nanoparticles (TiO2NPs) on Phaseolus vulgaris L. under salinity stress. PLoS ONE 2020, 15, e0235355. [CrossRef] [PubMed]

60. El-Sayed, A.; Enan, G.; Al-Mohammadi, A.-R.; Moustafa, H.A.; El-Gazzar, N. Detection, purification and elucidation of chemical structure and antiproliferative activity of taxol produced by Penicillium chrysogenum. Molecules 2020, 25, 4822. [CrossRef] [PubMed]

61. El-Gazzar, N.; Ismail, A.M. The potential use of Titanium, Silver and Selenium nanoparticles in controlling leaf blight of tomato caused by Alternaria alternata. Biocatal. Agric. Biotechnol. 2020, 27, 101708. [CrossRef]

62. El-Gazzar, N.; Almanaa, T.N.; Reda, R.M.; El Gaafary, M.; Rashwan, A.; Mahsoub, F. Assessment the using of silica nanoparticles $\left(\mathrm{SiO}_{2} \mathrm{NPs}\right)$ biosynthesized from rice husks by Trichoderma harzianum MF780864 as water lead adsorbent for immune status of Nile tilapia (Oreochromis niloticus). Saudi J. Biol. Sci. 2021, 28, 5119-5130. [CrossRef]

63. De Man, J.C.; Rogosa, M.; Sharpe, M.E. A Medium for Larson. In Block S.S. Disinfection, Sterilization and Preservation, 4th ed.; Morton, E.L., Alcohols, H.E., Eds.; Lea \& Febiger: Philadelphia, PA, USA, 1960.

64. Osman, A.; El-Gazzar, N.; Almanaa, T.N.; El-Hadary, A.; Sitohy, M. Lipolytic postbiotic from Lactobacillus paracasei manages metabolic syndrome in albino wistar rats. Molecules 2021, 26, 472. [CrossRef] [PubMed]

65. Holt, J.G. Facultatively anaerobic Gram-negative rods, subgroup 1: Family Enterobacteriaceae. In Bergey's Manual of Determinative Bacteriology, 9th ed.; Holt, J.G., Ed.; Lippincott Williams and Wilkins: Baltimore, MA, USA, 1994; pp. 175-189. ISBN 9780683006032.

66. Kurtzman, C.P.; Fell, J.W. The Yeasts a Taxonomic Study, 4th ed.; Elsevier: Amsterdam, The Netherlands, 1998, ISBN 978-0-12384708-9.

67. Performance Standards for Antimicrobial Disk Susceptibility Test: Approved Standard M2-A6, 6th ed.; National Committee for Clinical Laboratory Standards (NCCLS): Wayne, PA, USA, 2002.

68. Clinical and Laboratory Standards Institute (CLSI). Performance Standards for Antimicrobial Susceptibility Testing: Eighteenth Informational Supplement; CLSI: Wayne, PA, USA, 2008.

69. Durairaj, S.; Srinivasan, S.; Lakshmana-perumalsamy, P. In vitro antibacterial activity and stability of garlic extract at different $\mathrm{pH}$ and temperature. Electron. J. Biol. 2009, 5, 5-10.

70. El-Bahr, S.; Elbakery, A.; El-Gazzar, N.; Amin, A.; Al-Sultan, S.; Alfattah, M.; Shousha, S.; Alhojaily, S.; Shathele, M.; Sabeq, I.; et al. Biosynthesized iron oxide nanoparticles from Petroselinum crispum leaf extract mitigate lead-acetate-induced anemia in male albino rats: Hematological, biochemical and histopathological features. Toxics 2021, 9, 123. [CrossRef] [PubMed]

71. Victoria, C.N.; Harrison, J.; Cox, J.A.G. Dissecting the antimicrobial compostion of honey. Antibiotics 2019, 8, 251. [CrossRef]

72. Armstrong, R.A.; Eperjesi, F.; Gilmartin, B. An introduction to analysis of variance (ANOVA) with special reference to data from clinical experiments in optometry. Opthalmic Physiol. Opt. 2002, 20, 235-241. [CrossRef] 